\title{
Economic Valuation of Mangrove Forest Ecosystem in Tatapaan, South Minahasa, Indonesia
}

\author{
Steefra D. Mangkay ${ }^{1,2}$, Nuddin Harahab ${ }^{1,3}$, Bobby Polii ${ }^{1,4}$, Soemarno ${ }^{1,5}$ \\ ${ }^{1)}$ Environmentand Development Studies Program, Graduate School, University of Brawijaya, Indonesia \\ ${ }^{2)}$ Departement of Technic Industry, Faculty of Industrial Technology, Technology MinaesaInstutute, Indonesia \\ ${ }^{3}$ Departement of Fishery Economics, Faculty of Marine Sciences and Fishery, University of Brawijaya, \\ Indonesia \\ ${ }^{4)}$ Departement of Agriculture, Faculty of Agronomy of Sam Ratulangi, Indonesia \\ ${ }^{5)}$ Departement of Soil Science, Faculty of Agriculture, University of Brawijaya, Indonesia
}

\begin{abstract}
Mangroveforests in Tatapaan,South MinahasaRegencyis one of coastalresourceswith significant valuebecause it is included assupporting zoneforthe Bunaken National Park. There for thecoastal areabecome a very important partin thedevelopmentandconservationactivities. The research wasconductedinthe SondakenVillage, District of Tatapaan,SouthMinahasa Regencywhich aimed to (1) perform economic evaluation of mangrove resources, (2) analyze the potencies of mangroveecosystem, and(3) analyze mangrove contributionto the regional development.Mangrove forest ecosysteminthe Sondakenvillage apparentlyhas benefitsandfunctionsboth asan economicresourcesandecologicalresourcesfor human being incoastal areas ofTatapaan, as well as for conservation of the Bunaken NationalPark.Result of the study showed that Importance Value Indexvariableof mangroveforestsinthe SondakenVillage,District of Tatapaan isdominatedbyRhizophoraspeciesby 71,433(27\%);Avicenniaspeciesby 57,556(22\%);

Sonneratiaspeciesby53,775(20\%);Ceriopsamounts for 35 777(13\%); danBruguieraspeciesby25,995(10\%). Based oneconomic valuation, the economicvalue ofmangroveforestsas adirect benefit (direct use value)is amounts forRp.29.615.030peryear, indirect benefits(indirect use value)byRp.297.916.110peryear,optionalbenefit (option value)byRp.27.362.863peryear and existence benefit (existence value) by Rp.82.088.589 per year. Thus thetotaleconomicbenefits (Total economic value, TEV) ofmangroveforestsisRp.436.088.589peryear

Keywords: mangrove, EconomicValuation, ImportanceValueIndex
\end{abstract}

\section{Introduction}

Mangrove forest ecosystem is one of the coastal resources that plays an important role in the social, economic, and ecological aspects(Santoso, 2007)[1].The main function as a balanceing agent of coastal ecosystem and producer of human needs and other organisms(Cahyo.S,2007)[2]. Mangrove forest resources have the potential as a producer of wood and as a spawning ground, nursery ground, as well as a feeding ground for fishes and other marine lifes, also serves as the barrier of sea waves and sea water intrusion into the ground (Barbier, 2007[3].The mangrove litter are foods for marine biota and its decomposition released nutrients into the water which determines productivity of the surrounding waters (Sathirathai 2001)[4].

The magnitude of benefits of the mangrove forests ecosystem encourage the high level of its exploitation and usually resulting in degradation of mangrove ecosystems and mangrove forest conversion(Sathirathai, 2011[4]). This is related to the human actions that do not understand the importance of the sustainability of mangrove forests. The human community simply assesses mangrove forests in terms of its economy benefits, without regard to its ecological benefits (Bengen, 2000)[5].

Of the approximately 15.9 million hectares of mangrove forests in the world, about $27 \%$ or 4.25 million ha are in Indonesia (Bengen, 2000)[5]. Mangrove forest area in North Sulawesi 7.348 ha, mangrove forest in South Minahasa 423 ha and mangrove area in Tatapaan district 873,6 ha (Bakosurtanal, 2009)[6]. According to Santoso (2007)[7], there were about $57 \%$ of the total area of mangrove in Indonesia is in a degraded condition, so that their ecological services are scarce.

Mangrove resources have an important role in the life of coastal communities. This mangrove natural resource management must be done wisely, because it takes a long time to restore their damages (Kusmana, dkk.2003)[8].. The wise management of mangrove resources is the sustainable utilization of mangrove resources (Cahyo, 2007)[2].

Mangrove forest ecosystem are made up of the mangrove vegetation that grow in the area of beaches and estuaries that are affected by the ocean tides, this ecosystem has a variety of functions(Bengen, 2000)[5]. Mangrove forest ecosystems have important benefits and functions as an economic resources and ecological resources for human life. Therefore the existence of mangrove forests should be preserved (Sathirathai, 2011)[4]). Value of mangrove forests ecosystem need to be evaluated to determine the value that would be lost 
and the potential negative impact for human life if the mangrove ecosystem are degraded (R.Kerry Turner,2010)[9]. This research aims to analyze the potential and economic value of mangrove forest ecosystems, and its contribution to society in the coastal area in the Sondaken village (Anonimous, 2011)[10].

\section{Research Method}

The research was conducted in the coastal village of Sondaken, sub-district of Tatapaan South Minahasa district, during June 2012 to October 2012. The research object is the mangrove forest ecosystem and its surrounding communities, as well as the users of mangrove resources, i.e. the rural families, and Government agencies. The sampling method in this research is Purposive sampling technique. Samples of coastal communities who were interviewed as many as 30 respondents. The respondents are members of communities who make use of mangrove forests, such as thefirewood collector and fishermen.An interview was conducted with an village apparatus and local forestry officials.

Research variables include: (1) the potential of mangrove forests, it is indicators are vegetation density, the frequency, dominance and Important Value Index. Potencies of non-vegetation are direct uses (benefits) of mangrove forests. (2) the direct use value, i.e. the value resulting from the utilization of mangrove forests directly, such as fishes and woods. (3) the indirect uses value (benefits), i.e. the value resulting from the indirect utilization of mangrove forests as a protector of the beach and barrier of sea water intrusion. (4) the options value, namely the economic value obtained from the potencies of direct uses and indirect uses of mangrove forests in the future, its indicator is the biodiversity.

Analysis of the volume of the stand is carried out to determine volume of the mangrove wood in each hectare areas. This data can be used to estimate the value of direct benefits of mangrove forests based on the volume of timber produced.Sampling method for vegetation analysis was conducted using the transect line (Dwi Kameluh,2010)[16]. Stages in the transects data collection, namely the meter placement toward the sea with starting positions have been marked (stakes or painting the tree and determine the plot), on the left and right of the line of longitude-transects are made a square with a size of $10 \mathrm{~m} \times 10 \mathrm{~m}$ for tree observation. There is one sample square of each transect lines and data collected in this sample square are the number of the individual tree, tree diameter $(\mathrm{cm})$, tree height $(\mathrm{m})$ and wood volume $(\mathrm{m} 3)$ (Table 2).

Analysis of the stand volume (their criteria are natural stands and the result of planting, location border, age of the stand and there is no minimum size area) is conducted to estimate the volume of the mangrove wood (Godstime K. et al 2011[15]. To get the volume of wood, it must be known in advance the height of tree and circle of trunk at the chest height (1.3 m) of the tree sample (Cahyo, 2007[2]). The volume of mangrove wood is estimated by using the formula (Santoso, 2007) :

$$
\mathrm{V}=(\operatorname{Lbd} \mathrm{xt}) \ldots \ldots \ldots \ldots \ldots \ldots \ldots \ldots \ldots \ldots 1)
$$

where: $\mathrm{V}=$ Volume of wood, $\mathrm{Lbd}=$ basal area $\left\{[(\text { diameter } / 100) \times 0.5]^{2}\right\} \times 3.14 ; \mathrm{T}=$ tree height $(\mathrm{m}) ; \Pi=3.14$. Results of this analysis indicate the potential of the stand volume per hectare of mangrove forests. This value can also be used as initial estimation in the economic valuation of mangrove wood. The economic value of the stand may be estimated by calculating the cubication of wood multiplied by the sales price per $\mathrm{m} 3$ of wood, multiplied by areas and minus by the cost of production. The selling price of the mangrove wood $\mathrm{Rp} 800,000$ with a production cost of Rp 350,000 and harvest cycle of 25 years (Benuet al., 2006)[11].

The ecological conditions of mangrove forests can be known by using indicators of species density, frequency, coverage area, and Important Value Index (IVI) of each species (Heriyanto,dkk, 2006)[17]. The IVI value being estimated by three calculations, i.e. the species density, frequency, and coverage area. Species density (Di) is the number of species-i stands in an area (square area which is $10 \mathrm{~m} \times 10 \mathrm{~m}$ ).

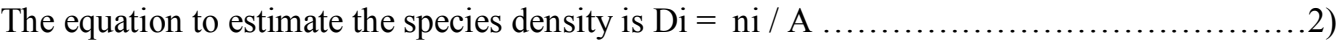

where is: $\mathrm{Di}=$ the density of the species (Rhizophora, Avicennia, Sonneratia, CeriopsTagal, Bruguiera, and Xylocarpus); $\mathrm{Ni}=$ the total amount of the species; $\mathrm{A}=$ total area of sampling area (square of $10 \mathrm{~m} \times 10 \mathrm{~m}$ ).

The value of this species density then is used to find the relative density of species (RDi). Relative density is the ratio between the number of species (ni) and the total amount of the all species $\left(\sum \mathrm{n}\right)$, with the equation: $\mathrm{RDi}=\left(\mathrm{ni} / \sum \mathrm{n}\right) \times 100$

Species Coverage (Ci) is a coverage area of the species in the area of square. The equation to calculate the species coverage is: $\left.\mathrm{Ci}=\sum \mathrm{BA} / \mathrm{A} \ldots \ldots \ldots \ldots \ldots \ldots \ldots . \ldots 4\right)$

where: $\mathrm{BA}=\pi \mathrm{DBH} 2 / \mathrm{A} ;(\pi=3.14)$; $\mathrm{DBH}=$ trunk diameter of the species (Rhizophora, Avicennia, Sonneratia, CeriopsTagal, Bruguiera, and Xylocarpus); $\mathrm{DBH}=\mathrm{CBH} / \pi ; \mathrm{CBH}$ is the circle of the chest-high trees; $\mathrm{A}=$ total area of sampling area (the area of a square of $10 \mathrm{~m} \times 10 \mathrm{~m}$ ).

The value of species coverage is used to calculate the relative coverage of species (RCi), i.e. the ratio of species coverage $(\mathrm{Ci})$ and a total coverage of all species $(\Sigma \mathrm{C})$, with the equation:

$\mathrm{RCi}=(\mathrm{Ci} / \Sigma \mathrm{C}) \times 100$

Species Frequency (Fi) is a chance discovery of a certain species in a sample plot (a square of $10 \mathrm{~m} \times 10 \mathrm{~m}$ ) ) which is observed: 
$\mathrm{Fi}=\mathrm{Pi} / \sum \mathrm{P}$

where $\mathrm{Fi}$ is the species frequency, $\mathrm{Pi}$ is the number of sample plots (a square of $10 \mathrm{~m} \times 10 \mathrm{~m}$ ) where found a certain species. While $\mathrm{P}$ is the total number of sample plots. The value of Fi is used to estimate value of the Relative Frequencyof the species (RFi), which is the ratio between the species frequency (Fi) and the total requency $\left(\sum \mathrm{F}\right)$ :

$\left.\mathrm{RFi}=\left(\mathrm{Fi} / \sum \mathrm{F}\right) \mathrm{x} 100\right)$

Importance Value Index (IVI) is the sum of the value of species density (RDi), the relative Frequencies (RFi), and relative coverage $(\mathrm{RCi})$.

$\mathrm{IVI}=\mathrm{RDi}+\mathrm{RFi}+\mathrm{RCi}$

These important values to give an insight into the role of a species in the mangrove ecosystems. Important value index has a range of between 0 - 300 (Benudkk., 2011)[11].

The direct use value of mangrove ecosystems is a value generated from the utilization of a mangrove resources directly. Direct uses is defined as benefits (goods and services) that can be consumed. In the context of the mangrove ecosystem is the result of mangrove forests that are directly used by surrounding communities. In this research, indicator of the direct use are fishes and wood production(Harahab. N, 2008)[12]. Direct uses value of mangrove forests was estimated by the equation:

$\mathrm{DUV}=\sum$ DUV I

Where: DUV = Direct use value; DUV1 = wood value; DUV2 $=$ fishes value(data of catch fishes and fishes sell price at the location).

Indirect use value is the value of the mangrove resources benefits utilized indirectly by the human society. Indirect use value of mangrove forests can be either physical benefits, namely as the barrier of sea abrasion. Valuation of mangrove forests can physically being estimated with the function of mangrove forests as a abrasion barrier. This estimation used the replacement cost method, i.e. the cost to manufacture the breakwater along the coastline protected by the mangrove forests (Sathirathai, 2011)[4].

Option value for mangrove forests being estimated with the benefit transfer method, i.e. by way of estimating benefit of resources from other places then the benefit is transferred to obtain an estimate of the local resource benefits. In this study is used the estimation of the biodiversity value of mangrove ecosystems. According to Ruitenbeek (1991), in Dahuri, 2003)[13], the value of biodiversity of the Indonesia mangrove forest amounted to US $\$ 1,500$ per $\mathrm{km} 2$. This value can be used around the mangrove forests that existed in Indonesia if forest ecosystems are ecologically important and it is maintained naturally.

Option Value is estimated using the follow equation :

$\mathrm{OV}=\mathrm{US} \$ 15$ per ha $\mathrm{x}$ area of mangrove forest...

where $\mathrm{OV}=$ option value; area of forest mangrove in research location 276,7 ha.

Existence Value is a value that is already attached to the resource (Fauzi, 2010)[14]. This value includes non-use values that can be obtained based on willingness to pay someone to the existence of mangrove forests. The existence value of the scarce species, endangered species, protected species, and the protected natural habitat is about US \$ $30 \mathrm{ha} / \mathrm{yr}$.EV $=\mathrm{US} \$ 30$ per ha $\mathrm{x}$ area of mangrove forest.

All of the benefit value (the calculation results) are quantified becomes the value of money (rupiahs) in the following ways:

1. Market value. This approach is used to calculate the economic value of commodities that can be used directly from the mangrove resources by calculating the catch fishes is multiplied by the selling price of the fishes.

2. Indirect Value. This approach to assess the indirect benefits from the mangrove forests. Mangrove forests produce the perceived benefits indirectly by the human communities, such as preventing sea abrasion which can be quantified by calculating the length of the break-water that is multiplied by cost of the break-water per meter. The second indirect benefit is the mangrove forest as the barrier of the influx of sea water into the land or barrier of the sea water intrusion, it can be estimated by the replacement cost method.

3. The existence value is perceived by the public benefits from the existence of endangered species, protected species, and natural habitat protection

4. Total Economic Value (TEV). This value is the summation of the entire economic value of mangrove forest benefits that have been identified and quantified. Value of the total economic benefits (TEV) is calculated by the equation:TEV $=\mathrm{DV}+\mathrm{IV}+\mathrm{OV}+\mathrm{EV}$

where $: \mathrm{TEV}=$ Total economic value; $\mathrm{DV}=$ direct use value; $\mathrm{IV}=$ indirect use value; $\mathrm{OV}=$ option value; $\mathrm{EV}=$ existence value

\section{Results And Discussion}

Sondaken village is located in subdistrictTatapaan, South Minahasa district, a coastal village that is directly adjacent to the southern part of The Bunaken National Park. The villagers of Sondakentotalled 649 persons and an area of 1200 ha. Sondaken village community are the ethnic group of Minahasa and Sangihe. 
Most of the population have a livelihood on fisheries and plantations sector. A portion of the territory was a plantation bordering the Celebes Sea, so some of people also became a fisherman.

The mangrove forest in Sondaken Village of 276.70 ha, its condition is quite good because the local communities manage this mangrove forests appropriately. This is suggested by the inclusion of mangrove preservation into the village regulation. Sondaken village community already understands about the mangrove function and the negative impacts if the mangrove forests are degraded.

Results of vegetation analysis indicate that the species of mangrove at this location are Rhizophoraspp (Lolaro), Ceriopstagal (Kayu-Ting), Bruguieragymnorhiza (makurung), Sonneratiacaseolaris (Posi-posi) and Avicennia spp. (Api-api) (Figure 1 and 2). Rhizophora spp. have the highest Important Value Index (IVI) of 72.09, followed by Avicennia spp. (14.33) Sonneratiacaseolaris, (53.77), Ceriopstagal (35.78), and Bruguieragymnorhiza (4.49) (Table 1).

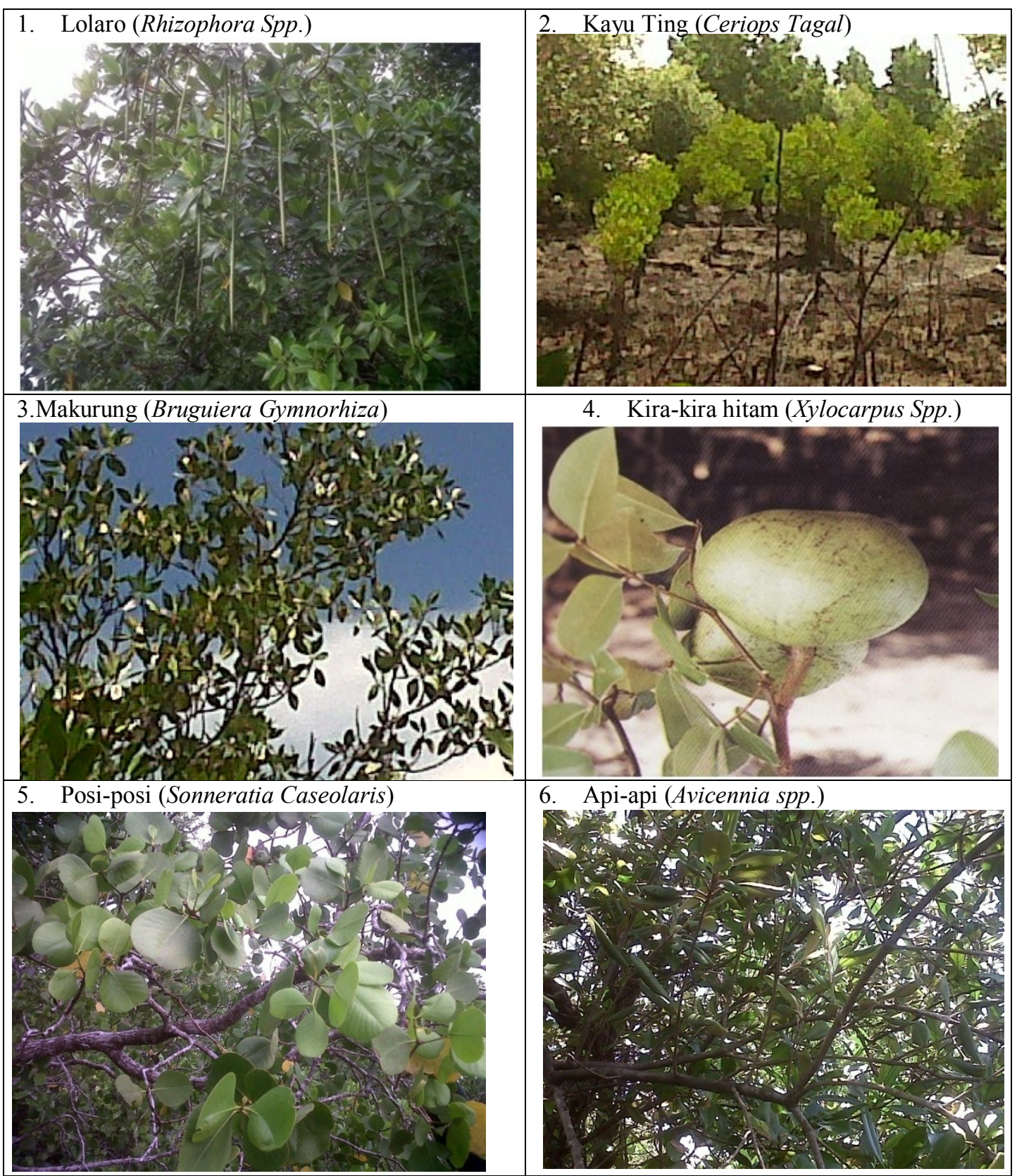

Figure 2.Mangrove Vegetation in Tatapaan subdistrict 
Table 1. Important value index(IVI) of Mangrove Species in Sondaken Village

\begin{tabular}{lcccc} 
No. Species & $\begin{array}{c}\text { Relative } \\
\text { Density }\end{array}$ & $\begin{array}{l}\text { Relative } \\
\text { Frequency }\end{array}$ & $\begin{array}{l}\text { Relative } \\
\text { Coverage }\end{array}$ & $\begin{array}{l}\text { Important } \\
\text { Value } \\
\text { Index (IVI) }\end{array}$ \\
\hline 1. Rhizophora spp. & 22.723 & 14.564 & 34.146 & 71.433 \\
2. Ceriops tagal & 13.636 & 8.726 & 13.415 & 35.777 \\
3. Bruguiera gymnorhiza & 12.121 & 7.776 & 6.098 & 25.995 \\
4. Xylocarpus spp & 7.576 & 4.857 & 7.500 & 19.933 \\
5. Sonneratia caseolaris & 18.182 & 11.664 & 23.929 & 53.775 \\
6. Avicennia spp. & 25.757 & 16.489 & 15.310 & 57.556 \\
\hline
\end{tabular}

Economic valuation of mangrove ecosystem in the Sondakenvillage:

TEV $($ Total economic value $)=\mathrm{DV}+\mathrm{IV}+\mathrm{OV}+\mathrm{EV}$

\section{a. Direct uses value}

Field observations and identification of the mangrove in the Sondaken village shows the six mangrove species, namely, Rhizophora spp. (Lolaro), CeriopsTagal (Kayu-ting), Bruguieragymnorhiza (Makurung), Xylocarpus spp. (Kira-kiraHitam), Sonneratiacaseolaris, (Posi-posi) and Avicennia (Api-api).

The analysis about the potential of wood based on the diameter and height of the tree shows the volume of the mangrove wood of $80,55 \mathrm{~m} 3$ per hectare. (This value is obtained from the calculation of the volume of all scpecies of mangrove in one hectare of mangrove forest)

Table 2. Estimation of mangrove wood volume in the Sondaken(area of 276,7 ha)

\begin{tabular}{|c|c|c|c|c|}
\hline No. Species & $\begin{array}{l}\text { Number } \\
\text { Of Individu }\end{array}$ & $\begin{array}{l}\text { Diameter } \\
(\mathrm{cm})\end{array}$ & $\begin{array}{l}\text { Height } \\
\text { (m) }\end{array}$ & $\begin{array}{c}\text { Volume } \\
\left(\mathrm{m}^{3}\right)\end{array}$ \\
\hline 1. Rhizophora spp. & 15 & 60 & 1.30 & 0.1367 \\
\hline 2. Ceriopstagal & 9 & 37 & 1.30 & 0.1391 \\
\hline 3. Bruguieragymnorhiza & 8 & 25 & 1.30 & 0.1637 \\
\hline 4. Xylocarpus spp. & 5 & 28 & 1.30 & 0.0637 \\
\hline 5. Sonneratiacaseolaris & 12 & 35 & 1.30 & 0.0799 \\
\hline 6. Avecennia spp. & 17 & 40 & 1.30 & 0.1630 \\
\hline
\end{tabular}

0.8055

Source : Valuation in one square of $10 \mathrm{~m} \times 10 \mathrm{~m}$.

The analysis of the potential of commercial woods in the mangrove forest is $22288,18 \mathrm{~m} 3$, so the value

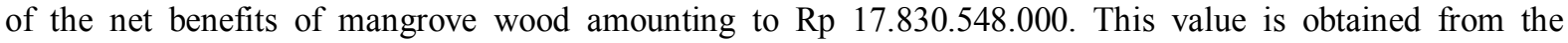
multiplication between wood volume by price per cubic meter of the mangrove wood of Rp 800,000, and minus by the cost of the management of Rp 350,000 per cubic meter. Assuming a 25 year cutting cycle, it is estimated by the productivity method, the potential value of the mangrove wood about $\mathrm{Rp} 157.200$ per year.

Firewood taken by the surrounding communities is the dry wood in the mangrove forests and it is sold for $\mathrm{Rp} 1,250$ per bunch. In a year the firewood produced reaches 75 bunches. The value of the firewood is obtained by means of multiplying the selling price of wood per bunch with a volume of firewood that is produced, so the obtained value amounting to $\mathrm{Rp} 93.750$ per year.

Fishing is done by using the fishing tools of fishing-rods and fishing trawl fishing. Benefit value of this fishing catch is $\mathrm{Rp} 36.500 .000$ per year. This value is obtained from the sale of fish for $\mathrm{Rp} 20,000$ per kilogram, multiplied by the average catches is $1825 \mathrm{~kg}$. The fishing cost Rp 6.978 .720 per year, and the net value of this fishing is Rp 29.521.280 per year.

b. The indirect benefits of mangrove forests in the Sondakenvillage is as the barrier of abrasion. The value of this benefit may be estimated by the method of replacement costs, i.e. the cost of making the breakwaters. According to the Public Works Agency of North Sulawesi (2009), to build a breakwater with a size of $37,5 \mathrm{~m} \times 2 \mathrm{~m} \times 2.5 \mathrm{~m}$ with a five-year durability is needed the building cost about Rp 265.727 .775 or Rp. 7.086.074 per meter. Coastline length of 75 metres. The value of the building cost of the breakwater is then multiplied by the length of the coastline protected by mangrove forests, that is, as long as 75 meters. Breakwater buildings are assumed to be able to replace the function of mangrove forests as a breakwater barrier along the 
coastline at Sondaken Village. The value of indirect benefits of mangrove forests as a barrier of abrasion is Rp 531.455.550. This value is then divided by five to obtain the average value per year. Thus the value of the benefit is about Rp 106.291.110 per year.

The second indirect benefit of the mangrove forest is its function as the filter of sea water intrusion into the land. This benefit can be estimated by using the method of replacement cost. This method is used to valuate the ecosystem who has suffered degrade, so the community should accept the losses or the community would have to pay a certain amount to get back the goods or services that has been lost.

Results of field analysis show that the local communities around the beach are threatened to scarce of fresh water when there is no mangrove forests. Thus the calculation of the economic value of this function is estimated with the value of the use of water to meet the needs of each household. Sondaken Village's population was 649 persons and consists of 179 households. Need of fresh water to cook and drink is about 1 gallon per household, with a price of Ro 3000/gallon. Thus the average need per year for each household is 365 gallons, so the costs to obtain fresh water Rp. 1.095.000/year. So the value of freshwater needs a year for all household is Rp. 191.625.000.

According to Ruitenbeek (Dahuri, 2003)[13], the option value of mangrove forests as the biodiversity storage is US\$ $1,500 / \mathrm{km} 2$ per year, assuming the mangrove forests have an important ecological functions and it is maintained well. The areas of mangrove forests amounted to 276,7 ha, and the contribution of each hectare mangrove forest as a biodiversity storage is US\$ 75. The exchange rate of US\$ is Rp. 9.889, then the value of the contribution is considered as a biodiversity storage is amounted to Rp. 27.362 .863 per year.

Existence value (EV) of mangrove ecosystem includes the value of existence of endangered species, protected species, and the wildlife habitats. Assuming the value of the endangered species of US\$ 30 ha per year, areas of mangrove forest $276,7 \mathrm{ha}$, and the exchange rate of US\$ is Rp. 9889, the existence value (EV) of the mangrove forests is:

$\mathrm{EV}=\mathrm{US} \$ 30$ per ha $\mathrm{x}$ area of mangroveforest $=\mathrm{Rp} .82 .088 .589$ per year

Results of analysis show the total economic value of the mangrove forest in the Sondaken village is $\mathrm{Rp}$. 436.982.592 (Table 3).

Table3.Total use value of mangrove forest ecosystem in Sondaken Village

\begin{tabular}{clcc}
\hline No. & Kinds of value & Economic value $(\mathrm{Rp} /$ year $)$ & $(\%)$ \\
\hline 1. & Direct use value & 29.615 .030 & 6.78 \\
2. & Indirect use value & 297.916 .110 & 68.18 \\
3. & Option value & 27.362 .863 & 6.26 \\
4. & Existence value & 82.088 .589 & 18.78 \\
\hline & Total value & 436.982 .592 & 100.00 \\
\hline
\end{tabular}

\section{Conclusions}

1. Potencies of the mangrove forest ecosystem reflect the ecological condition of mangrove forests or the role of mangrove in the Sondaken village. Vegetation resources of mangrove forests in Sondaken Village is dominated by the Rhizophora (27\%); Avicennia, Sonneratia (22\%) (20\%), Ceriops, Bruguiera (13\%) (10\%) and Xylpcarpus (10\%).

2. The direct use value of the mangrove ecosystem for the firewood is Rp 93.750 per year, and for the fishing isRp 6.978.720 per year, the total direct use value mangrove ecosystem in the Sondaken village is $\mathrm{Rp} 29.521 .280$.

3. The indirect use value of mangrove forests are composed of a variety of ecological functions such as the filter of sea water intrusion and the barrier against the coastal abrasion. The value of indirect benefits of mangrove as the abrasion barrier is Rp. 106.291 .110 per year. Indirect benefits of mangroves as the filter of sea water intrusion isRp. 191.625 .000 per year. Total indirect use value of the mangrove forests amounted to Rp. 297.916.110 per year.

4. The option value of mangrove forest ecosystem as the biodiversity storage in the Sondaken village is estimated about Rp.27.362.869 per year. Existence value (EV) of mangrove ecosystem includes the value of existence of endangered species, protected species, and the wildlife habitats. The existence value of forest mangrove in the Sondaken village is estimated about Rp.82.088.589 ha per year. 
5. The total economic value of the mangrove forest ecosystem in the Sondaken village is amounted to Rp.436.982.592 per year. The mangrove forest ecosystem have the important benefits and functions as the economic and ecological resources for the people that were around. Therefore the existence of this mangrove forest ecosystemsshouldbe maintained as a sustainable development assets.

\section{Journal Paper:}

\section{References}

[1]. Barbier, E.B 2007, Valuing Ecosystem Services as Production Inputs. Economic Policy 22, 177229

[2]. SuthawanSathirthai and Edward.B.Barbier, 2010.Valuing Mangrove Conservation inSouthernThailand, Contemporary Economic Policy (ISSN 1074-3529) Vol. 1, No. 2,April 2011, 109-122.

[3]. R.Kerry Turner, Sian morse-Jones, and Brendan Fisher, 2010. Ecosystem Valuation, Annals of The New York Academy of Scienes, Ecological Economics Reviews.

[4]. Godstime K, James O.Adegoke, Ekechukwu Saba, Peter Nwilo, Joseph AkinyedeOsagie, 2011. Economic Valuation of Mangroves in the Niger Delta, A social- Ecological Analysis ,first edition 2011

\section{Books:}

[5]. Santoso, U. 2007. PermasalahandanSolusiPengelolaanLingkunganHidup di PropinsiBengkulu.Pertemuan PSL PT se-Sumatera tanggal 20 Februari 2006 di Pekanbaru.

[6]. Cahyo. Saparinto,2007.Pendayagunaan Ekosistem Mangrove.Dahara Prize Semarang.

[7]. Bengen.G.D,2000.PengenalandanPengelolaanEkosistemMangrove.

Bogor. PusatKajianSumberdayaPesisirdanLautan.InstitutPertanian Bogor.

[8]. BAKOSURTANAL, 2009. Peta Mangrove Indonesia. ISBN: 978:979-1266-39-0

[9]. Santoso,U.2007. PermasalahandanSolusiPengelolaanLingkunganHidup di PropinsiBengkulu.Pertemuan PSL PT se-Sumatera tanggal 20 Februari 2006 di Pekanbaru.

[10]. CecepKusmana,1996.NilaiEkologisEkosistemHutan Mangrove (Ekological Value of Mangrove Forest Ecosystem),JurusanManajemenHutanInstitutPertanian Bogor.

[11]. Anonimous, 2011. ProfilKabupatenMinahasa Selatan DinasKehutanandanPerikananKabupatenMinahasa Selatan.

[12]. Benu dkk.2011, ValuasiekonomiSumberdayaHutan Mangrove di DesaPalaesKecamatanLikupang Barat KabupatenMinahasa Utara. ASE- Volume 7,Mei 2011

[13]. DwiKemeluh.A, 2010. VegetasiPohon di HutanLindung, UIN Maliki Press Malang 2010.

[14]. Heryantodkk. 2006. KajianEkologidanPotensiPasakBumi (Eurycomalongifolia Jack.)KelompokHutan Sungai Manna-Sungai Nasal, Bengkulu. Bogor. Buletin Plasma Nutfah Vol.12 No.2.

\section{Dissertation}

[15]. Harahab. N. 2008, AnalisisEkonomiEkologiPerencanaan Wilayah Hutan Mangrove, Disertasi Program StudillmuPertanianMinatEkonomiPertanian.

Program

PascasarjanaFakultasPertanianUniversitasBrawijaya Malang 2008.

Proceeding Papaers:

[16]. Dahuri, R, Rais, J. Ginting, SP., Sitepu M,J., 2001. PengelolaanSumberDaya Wilayah PesisirdanLautanSecaraTerpadu.JakartaPradnyaParamitadalamProsidingPelatihanPengelolaan Wilayah PesisirTerpadu. 